\title{
In vitro studies on different extracts of fenugreek (Trigonella spruneriana BOISS.): Phytochemical profile, antioxidant activity, and enzyme inhibition potential
}

\author{
Volkan Aylanc $^{1}$ (D) | Bulent Eskin ${ }^{2}$ | Gokhan Zengin ${ }^{3}$ (D) | Mehmet Dursun ${ }^{4}$ | \\ Yavuz Selim Cakmak ${ }^{2}$ (D)
}

${ }^{1}$ Centro de Investigação de Montanha (CIMO), Instituto Politécnico de Bragança, Bragança, Portugal

${ }^{2}$ Department of Biotechnology and Molecular Biology, Faculty of Science and Letters, Aksaray University, Aksaray, Turkey

${ }^{3}$ Department of Biology, Science Faculty, Selcuk University, Konya, Turkey

${ }^{4}$ Department of Microbiology and Immunology, College of Letter and Science, Montana State University, Bozeman, MT, USA

\section{Correspondence}

Yavuz Selim Cakmak, Aksaray University, Faculty of Science and Arts, Department of Biotechnology and Molecular Biology, 68100 Aksaray, Turkey.

Email: cakmakys@aksaray.edu.tr

\begin{abstract}
The side effects of synthetic antioxidants make it necessary to find a natural alternative. Therefore, the current study investigates the potential of T. spruneriana as a new alternative in terms of natural bioactive components. In this context, antioxidant activity, enzyme inhibition, and phenolic compounds of different extracts including ethanol, methanol, ethyl acetate, and aqueous were identified. The results show that the ethyl acetate $(113.59 \pm 2.73 \mathrm{mg} \mathrm{GAE} / \mathrm{g})$ has the highest phenolic content, but ethanol extract has the highest scavenging activity for DPPH and TAC. The ethanol extract showed stronger inhibition on cholinesterase and $\alpha$-amylase compared to other extracts. Besides, 12 bioactive compounds were characterized in T. spruneriana extracts by HPLC-DAD. Our findings support that T. spruneriana could be considered as a new source of active phytochemicals, as well as provide remarkable data on biological activities of some main enzymes playing role in the healing of hyperpigmentation, Alzheimer, and diabetes.
\end{abstract}

\section{Practical applications}

This study reports the total content, types and amounts of bioactive compounds and potential beneficial bioactivities of the different extracts of $T$. spruneriana. Trigonella is abundant in nature and spread over a wide geographical area, and is used in making cheese, pastries, spices, and sausages in different countries, as well as for antidiabetic purposes. Trigonella leaves are a good source of bioactive compounds that contain compounds like quercetin, catechin, cinnamic acid, and coumaric acid, along with it have also a high content of soluble fibers and is suggested for body weight control. Apart from being the first study conducted to point out the potential of $T$. spruneriana as being a natural food additive, this study also demonstrated its medicinal importance by revealing the anti-hyperpigmentation, antidiabetic, neuroprotective, and antioxidant properties of $T$. spruneriana.

\section{KEYWORDS}

antidiabetic, anti-hyperpigmentation, antioxidants, bioactive compounds, enzyme inhibition, Trigonella 


\section{1 | INTRODUCTION}

Trigonella species known as fenugreek, belong to the family Fabaceae that contains about 135 species most of which spread in the Mediterranean, Europe, Asia, Africa, and North America (Mabberley, 1997). Trigonella species are the most abundant plants in the pasture composition and are an important forage plant with high protein content, especially in animal husbandry areas (Ranjbar \& Zahra, 2016). The leaves of Trigonella are rich in a wide variety of minerals, vitamins, and especially choline, while the seeds contain high-fiber structures and proteins, as well as neutral lipids, glycolipids, and phospholipids, and also have an aromatic, galactogogue, and antibacterial effect (Shankaracharya, Anandaraman, \& Natarajan, 1973; Srinivasan, 2006).

Trigonella species were used as medicinal plants since ancient ages and are rich in calcium, iron, carotenes, and phytochemicals (Bhanger, Bukhari, \& Memon, 2008), along with being also a good source of soluble dietary fibers which is suggested for weight control programs (Burton-Freeman, 2000). Besides, the plant has high content of bioactive compounds such as gallic acid, caffeic acid, hydroxybenzoic acid, ferulic acid, myricetin, and kaempferol (Benziane, Acem, Aggad, \& Abdali, 2019; Hussain, Suradkar, Javaid, Akram, \& Parvez, 2016). Due to these beneficial ingredients and medicinal importance, Trigonella species can be a therapeutic agent and a good source of antioxidant dietary supplement. Many countries use this plant as spice and vegetable, particularly in Asian countries (Singh, Singh, Shukla, \& Singh, 2010). Furthermore, it is used to add more flavor to cheese in Switzerland, make bread in Egypt, produce artificial maple syrup in Germany, used as an antidiabetic herb in Israel and in traditional pastry and sausage production in Turkey (Altuntaş, Özgöz, \& Taşer, 2005; Rajagopalan, 1998).

Today's common lifestyle related diseases like diabetes, cancer, cardiovascular diseases, neurodegenerative diseases, hypertension, hyperlipidemia, and digestive disorders are leading to health problems in many countries. Synthetic food additives are known to have an impact on these health problems due to carcinogenic and toxic effects (Carocho, Barreiro, Morales, \& Ferreira, 2014). Recently, the tendency toward the use of natural bioactive components as a food additive has increased because of its rapid recovery feature in the body (da Silva, Barreira, \& Oliveira, 2016), and its long-term effects compared to synthetic food additives. In this regard, it has been shown that there is a strong relationship between reducing the risk of developing common diseases and dietary bioactive compounds (Genkinger, Platz, Hoffman, Comstock, \& Helzlsouer, 2004; Willett, 2002).

Free radicals are molecules/molecular fragments that have unpaired free electron(s), derived from many different origins such as drug, ultraviolet light, hypoxia, ionizing radiation, cell metabolism (internal source), nutrient deprivation, and heavy metals. Excessive formation of free radicals causes oxidative stress. High levels of oxidative stress in living organisms damage biomolecules like proteins, DNA, and lipids (Chandra, Salman, Mohd, Sweety, \& Ali, 2015). Therefore, it causes many diseases to occur, including neurodegenerative (Gandhi
\& Abramov, 2012), cardiovascular (Rochette et al., 2013), diabetes (Avalos-Soriano, la Cruz-Cordero, Rosado, \& Garcia-Gasca, 2016), hypertension, and malignancies (Abas \& Naguib, 2019). Antioxidants can prevent and reduce these diseases by inhibiting free radicals oxidating biological molecules (Joana Gil-Chávez et al., 2013).

Although many reports on Trigonella have been stated in the literature, yet, there are neither studies conducted on enzymes nor phytochemical compounds obtained from T. spruneriana. Studies on T. spruneriana are limited and generally focused on geographical distribution, morphology (Martin, Akan, Ekici, \& Aytac, 2011), cytogenetics (Ranjbar \& Zahra, 2016), and taxonomy (Khandani, Assadi, Nejadsatari, \& Mehregan, 2016). The purpose of current study was to investigate amounts of phytochemicals (total phenolics and flavonoids), antioxidant properties, enzyme-inhibiting activities, and main profile of phenolic compounds of different $T$. spruneriana extracts.

\section{MATERIALS AND METHODS}

\section{1 | Chemicals}

All chemicals used to determine antioxidant and enzyme inhibition activities were analytical grade and obtained from Sigma Chemical Co. (Sigma-Aldrich St. Louis, MO, USA).

\section{2 | Plant materials}

The aerial parts of $T$. spruneriana were collected from Karaoren Village (Aksaray-Turkey) during the vegetation period in February 2015 and were identified by botanist experts Assist. Prof. Dr. Bulent Eskin and Dr. Mustafa Keskin.

\section{3 | Preparation of extracts}

T. spruneriana samples were pressed and air-dried in the dark at room temperature. Fully dried samples were milled using a commercial blender. Powdered samples were weighed in $15 \mathrm{~g}$ each in order to obtain $\mathrm{MeOH}, \mathrm{EtOH}, \mathrm{EA}$, and $\mathrm{AQ}$ extract. The $\mathrm{MeOH}, \mathrm{EtOH}$ and $\mathrm{EA}$ extracts were subjected to extraction using the a Soxhlet apparatus for 6-8 hr, while the AQ extract was performed by steeping in boiling water for $30 \mathrm{~min}$. Then, the extracts were filtered using Whatman filter paper and the solvent was evaporated completely at $40-50^{\circ} \mathrm{C}$ with a Rotary Evaporator under vacuum (Aktumsek, Zengin, Guler, Cakmak, \& Duran, 2013). Stock solutions were prepared from these extracts as $2 \mathrm{mg} / \mathrm{ml}$ prior to analysis.

\subsection{Profile of bioactive compounds}

The contents of total bioactive substance as phenolics (TPC) and flavonoids (TFC) of different extracts from $T$. spruneriana were 
TABLE 1 Total phenolic and flavonoid contents, ferric ion reducing power activity, and total antioxidant capacity of the obtained different extracts from $T$. spruneriana

\begin{tabular}{|c|c|c|c|c|}
\hline Extracts & $\begin{array}{l}\mathrm{TPC}^{\mathrm{a}} \text { (mg GAE/g } \\
\text { extract) }\end{array}$ & $\begin{array}{l}\mathrm{TFC}^{\mathrm{b}} \text { (mg QE/g } \\
\text { extract) }\end{array}$ & $\begin{array}{l}\text { FRAP }^{c} \text { (mg TE/g } \\
\text { extract) }\end{array}$ & $\begin{array}{l}\mathrm{TAC}^{\mathrm{d}} \text { (mg } \\
\mathrm{TE} / \mathrm{g} \text { extract) }\end{array}$ \\
\hline $\mathrm{MeOH}$ & $35.41 \pm 3.37^{e}$ & $89.90 \pm 0.53$ & $78.95 \pm 1.14$ & $47.00 \pm 2.98$ \\
\hline $\mathrm{EtOH}$ & $55.64 \pm 1.45$ & $30.08 \pm 1.14$ & $77.57 \pm 3.83$ & $65.75 \pm 3.25$ \\
\hline EA & $113.59 \pm 2.73$ & $8.69 \pm 0.68$ & $75.64 \pm 4.98$ & $62.62 \pm 2.21$ \\
\hline $\mathrm{AQ}$ & $18.59 \pm 2.73$ & $19.70 \pm 0.88$ & $45.60 \pm 0.83$ & $15.04 \pm 0.89$ \\
\hline
\end{tabular}

${ }^{\mathrm{a}} \mathrm{TPC}$ expressed as gallic acid equivalent (mg GAE g ${ }^{-1}$ extract).

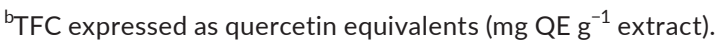

${ }^{\mathrm{C}} \mathrm{FRAP}$ expressed as trolox equivalents ( $\mathrm{mg} \mathrm{TE} \mathrm{g}^{-1}$ extract).

${ }^{\mathrm{d}} \mathrm{TAC}$ expressed as trolox equivalents ( $\mathrm{mg} \mathrm{TE} \mathrm{g}^{-1}$ extract).

eValues expressed are means $\pm S D$. analyzed spectrophotometrically by using Beckman Coulter DU 730, LifeScience UV/VIS Spectrophotometer. The results were calculated as equivalents of gallic acid and quercetin for TPC and TFC, respectively (Uysal et al., 2017).

\section{5 | Antioxidant activity}

The antioxidant activities of the obtained plant extracts were determined by DPPH radical-scavenging activity, ferric ion reducing antioxidant power (FRAP), and total antioxidant capacity (TAC) (by phosphomolybdate assay) analyzes (Uysal et al., 2017). The findings are expressed as trolox equivalent for both FRAP and TAC. Also, in $\mathrm{DPPH}$ analysis, $\mathrm{IC}_{50}$ values which are scavenging concentration to $50 \%$ of free radicals were calculated using concentration-inhibition graphics for each extract.

\subsection{HPLC-DAD analysis of phenolic compounds}

The phenolic compounds of $T$. spruneriana extracts were analyzed in HPLC (Agilent 1,290 Infinity) equipped with a C18 column and diode-array detector (DAD) as detailed in an earlier study (Caponio, Alloggio, \& Gomes, 1999). We used as mobile phase $3 \%$ of acetic acid $(\mathrm{A})$ and $\mathrm{MeOH}(\mathrm{B})$. The following gradient program was applied: $95 \% \mathrm{~A} / 5 \%$ B for $3 \mathrm{~min}, 80 \% \mathrm{~A} / 20 \%$ B for $15 \mathrm{~min}$, isocratic for $2 \mathrm{~min}$, $60 \% A / 40 \%$ B for 10 min, 50\% A/50\% B for 10 min and until the finish $100 \%$ B (10 min). The T. spruneriana extracts were prepared in methanol with a concentration of $20 \mathrm{mg} / \mathrm{ml}$ and the injection volumes were $10 \mu \mathrm{l}$.

\section{7 | In vitro enzyme inhibition activities}

Potential enzyme inhibition activities of obtained extracts from $T$. spruneriana with different solvents were successfully tested on $\alpha$-amylase, $\alpha$-glucosidase, acetylcholinesterase (AChE), butyrylcholinesterase (BChE), and tyrosinase enzymes. The potential antienzymatic capabilities of $T$. spruneriana extracts were performed as previously reported by Uysal et al. (2017). Enzyme inhibition abilities of extracts were denoted as the equivalent of galantamine (GALAE) for $\mathrm{AChE}$ and $\mathrm{BChE}$, acarbose (ACAE) for $\alpha$-amylase, $\alpha$-glucosidase, and kojic acid (KAE) for tyrosinase. The explanation of enzyme inhibition assays is given in detail in our previous study (Uysal et al., 2017).

\subsection{Statistical analysis}

All assays were carried out in three replicates and the obtained results were denoted as mean \pm standard deviation (SD). The obtained data were analyzed using SPPS 26 software (Chicago, IL, USA) and Analysis-it software Excel Tool Pak (Leeds, LSE 1HS, UK). One-way analysis of variance was conducted to see whether there is a statistical significance. $p<.05$ was considered as significant. Also, Pearson and Spearman correlation coefficients were calculated to ascertain the relationship between total bioactive contents and biological activities of extracts.

\section{3 | RESULTS AND DISCUSSION}

\section{1 | TPC}

Phenolics are among the most important biologically active compounds that contain phenol rings in their structures and are natural compounds with anticancer, antidiabetic, antioxidant, and antimicrobial effects. According to the results given in Table 1, the TPC of T. spruneriana extracts ranged from 18.59 to $113.59 \mathrm{mg} \mathrm{GAE} / \mathrm{g}$ extract, and maximum TPC was found in EA extract (113.59 mg GAE/g extract) followed by $\mathrm{EtOH}, \mathrm{MeOH}$, and $\mathrm{AQ}$ extracts, respectively. It is known that different solvents used for extraction have a significant effect on the tested plant extracts. The recovery of phenolic compounds of the T. spruneriana plant was recorded in the best EA solvent and this indicates that the TFC of the T. spruneriana plant was extracted better in semi-polar solvents such as EA.

Previous studies on various plant species have also reported that phenolic levels differed based on the use of different solvents (Alothman, Bhat, \& Karim, 2009; Rusak, Komes, Likić, Horžić, $\&$ Kovač, 2008). As of the current date, there is only one study in the literature on the TPC of T. spruneriana and the TPC in $\mathrm{MeOH}$ 
extract was found as $83.46 \mathrm{mg}$ GAE/g extract (Uras Güngör, İlçim, \& Kökdil, 2017). In the present study, the TPC of $\mathrm{MeOH}$ extract was measured as $35.41 \mathrm{mg} \mathrm{GAE} / \mathrm{g}$ extract. In our study, different values of TPC can be attributed to various factors such as environmental and genetic (Fratianni, Tucci, De Palma, Pepe, \& Nazzaro, 2007). In a study on Trigonella monantha (Esmaeili, Rashidi, \& Rezazadeh, 2012), the TPC of the plant was found lower in $\mathrm{MeOH}$ extract $(22.36 \mathrm{mg}$ $\mathrm{GAE} / \mathrm{g}$ ) compared to our findings. Chatterjee, Variyar, and Sharma (2009) investigated the TPC of Trigonella foenum and demonstrated that the phenolic content was in the range of 81-84 mg GAE equivalent per dry weight. Many studies indicate that phenolic compounds could make significant contributions to antioxidant action and, thus, plants having high amounts of phenolic compounds may be used as natural antioxidant sources. The results of this work support that the TPC of T. spruneriana extracts was found to vary significantly based on the type of solvent used.

\section{2 | TFC}

Flavonoids are common compounds found in herbal food, derived from metabolites such as carbohydrates and amino acids, needed for the vital activities of plants. Furthermore, flavonoids have many pharmacological features, and they have many positive effects on health (CF Bodewes et al., 2011). In the results given in Table 1, the highest TFC was seen in $\mathrm{MeOH}$ extract (89.90 mg QE/g), while the lowest flavonoid content was determined in EA extract $(8.69 \mathrm{mg}$ $\mathrm{QE} / \mathrm{g}$ ). Studies on the TFC of Trigonella species are quite limited in the literature. Uras Güngör et al. (2017) researched the TFC of different Trigonella species and reported the TFC value of T. spruneriana as $62.85 \mathrm{mg} \mathrm{RE} / \mathrm{g}$ in $\mathrm{MeOH}$ extract. The results obtained in this study were found to be in the same range as of the results obtained in other studies on different Trigonella species (Esmaeili et al., 2012; Güngör, Güzel, İlçim, \& Kökdil, 2014; Jaradat, Shawahna, Hussein, \& Al-Lahham, 2016). As in the TPC, the TFC values were also significantly affected depending on the type of the solvents used. In the correlation analysis on the content of total bioactive substance of $T$. spruneriana extracts, a moderately negative correlation $(r=-.460)$ was found between TPC and TFC.

\section{3 | DPPH assay}

Measurement of free radical-scavenging activity of $T$. spruneriana was detected using the DPPH assay. The obtained results are given in Figure 1. Accordingly, $\mathrm{MeOH}$ and $\mathrm{EtOH}$ extracts showed higher inhibition rates compared to other extracts and DPPH radical scavenging activity between both fractions is not significantly different. The minimum activity was determined in the AQ extract. This may be due to the low phenolic content of the AQ extract. In a previously reported study, T. spruneriana showed $21.11 \%$ inhibition of DPPH radical in $\mathrm{MeOH}$ extract (Uras Güngör et al., 2017). According to the reported results by Jaradat et al. (2016), it was measured that $\mathrm{MeOH}$ extracts of Trigonella arabica and Trigonella berythea showed $23.2 \%$ and $48.3 \%$ inhibition, respectively. Additionally, in the statistical analysis applied to explain the relationship between DPPH radicalscavenging activity of total bioactive compounds, there is a direct relationship between TPC and DPPH radical scavenging antioxidant activity at $200 \mu \mathrm{g} / \mathrm{ml}(p<.05)$. Interestingly, no direct relationship was found between TPC and DPPH at concentrations of 500 and $1,000 \mu \mathrm{g} / \mathrm{ml}$. Contrarily, there was no significant relationship between TFC and DPPH in the studied concentrations.

In this method, $I_{50}$ values were also calculated for each extract and standard substance butylated hydroxytoluene (BHT), which is the concentration that removes $50 \%$ of the DPPH radical. Based on these values, the highest activity was observed in $\mathrm{EtOH}$ extract with $3.87 \pm 0.09 \mathrm{mg} / \mathrm{ml}$. The $\mathrm{IC}_{50}$ value of $\mathrm{BHT}$ is $0.03 \pm 0.38 \mathrm{mg} / \mathrm{ml}$. $\mathrm{MeOH}, \mathrm{EA}$ and $\mathrm{AQ}$ extracts were determined $4.00 \pm 0.07 \mathrm{mg} / \mathrm{ml}$, $4.51 \pm 0.27 \mathrm{mg} / \mathrm{ml}$, and $5.28 \pm 0.58 \mathrm{mg} / \mathrm{ml}$, respectively. The $\mathrm{IC}_{50}$ values obtained in the present study were found moderate or relatively higher in free radical-scavenging activity compared to previous studies on Trigonella species (Jaradat et al., 2016; Kenny, Smyth, Hewage, \& Brunton, 2013).

\section{4 | FRAP assay}

Because the antioxidant activity of a substance is generally related to its reducing capacity the FRAP analysis ensures a fast and reliable way to evaluate the antioxidant activity of the compounds. To this end, the

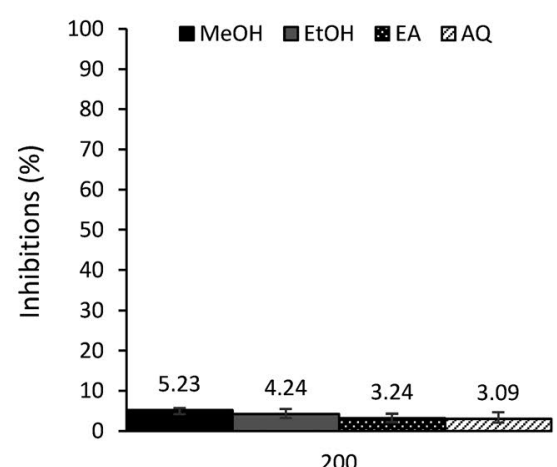

200

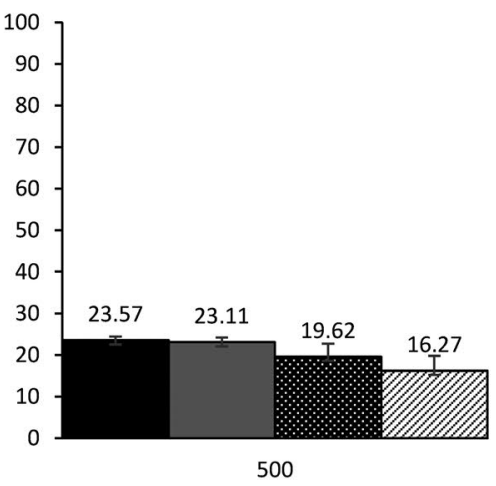

500

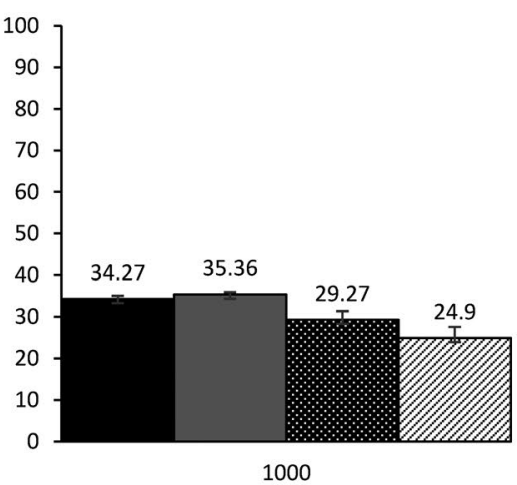

Concentrations $(\mu \mathrm{g} / \mathrm{mL})$

FIGURE 1 DPPH radical scavenging activity of $\mathrm{MeOH}$, EtOH, EA and AQ extract of T. spruneriana in different concentrations 
FRAP $\left(\mathrm{Fe}^{3+} \rightarrow \mathrm{Fe}^{2+}\right.$ ) analysis was performed to evaluate the electron donor power of $T$. spruneriana extracts. In FRAP analysis, antioxidant substances in the plant cause a reducing of TPTZ/Fe ${ }^{3+}-\mathrm{TPTZ} / \mathrm{Fe}^{2+}$ and the formed iron complex can be observed by quantifying blue color at $593 \mathrm{~nm}$ (Huang, Ou, \& Prior, 2005). The reduction activities of $\mathrm{MeOH}, \mathrm{EtOH}, \mathrm{EA}$, and $\mathrm{AQ}$ extracts of $\mathrm{T}$. spruneriana are given in Table 1. A trend similar to DPPH radical scavenging analysis of different extracts appeared in FRAP analysis. Accordingly, the highest reducing power activity was determined in $\mathrm{MeOH}$ (78.95 mg TE/g extract) and EtOH (77.57 mg TE/g extract) having a value very close to it. These were followed by EA (75.64 mg TE/g extract), and the lowest value was determined in AQ extract ( $45.60 \mathrm{mg}$ TE/g extract).

Considering FRAP and also DPPH results, the polar components of $T$. spruneriana extracts exhibited higher antioxidant activity in polar solvents such as $\mathrm{MeOH}$ and $\mathrm{EtOH}$. This may be due to the dissolution of antioxidant compounds with different polarities in different solvents (Gong et al., 2012; Sultana, Anwar, \& Ashraf, 2009). Therefore, when the antioxidant capacity of plant extracts is determined, the used solvents are an important factor and this may need to be taken into consideration. The results of the current study were higher than those obtained by Premanath, Sudisha, Lakshmi Devi, and Aradhya (2011) on Trigonella foenum graecum L. Given the FRAP results shown in Table 1 demonstrated that extracts in terms of higher the TFC values showed high ferric reduction activity, generally. In the correlation analysis performed, a strong correlation was observed between TFC and FRAP. This situation has been stated in previous studies that there is a relationship between TFC and TPC and reducing power (Sathisha, Lingaraju, \& Prasad, 2011; Smeriglio et al., 2016).

\section{5 | TAC}

In the phosphomolybdenum determination of four different extracts of $T$. spruneriana, total antioxidant activities varied between 65.75 and $15.04 \mathrm{mg}$ TE/g extract. The maximum action was observed in EtOH extract followed by $\mathrm{EA}, \mathrm{MeOH}$, and $\mathrm{AQ}$ extracts, respectively (Table 1). Gupta and Prakash (2009) emphasized the TAC of Trigonella graecum as $1.294 .78 \mu \mathrm{mol}$ ascorbic acid/g sample. In another study, the TAC of Trigonella hamosa $\left(\mathrm{IC}_{50}=25.82 \mu \mathrm{g} / \mathrm{mL}\right.$ ) was determined (Shahat, Ibrahim, \& Alsaid, 2015). In addition, some authors have reported a poor relation between TPC and TFC and phosphomolybdenum analysis (Nićiforović et al., 2010; Sarikurkcu, Uren, Uren, Tepe, Cengiz, \& Kocak, 2015). Similarly, a poor correlation was obtained between TFC and phosphomolybdenum assay statistically. On the contrary, a significant positive correlation was found between methods of TPC and TAC.

\subsection{HPLC-DAD analysis of T. spruneriana}

The Folin method is a rapid and reliable one which is frequently used in comparing the same samples that gives basic information about phytochemicals. However, this method does not provide a complete information on the quantity nor quality of bioactive components in mixed test material. Hence, the identification of phenolic acids and flavonoids of different fractions ( $\mathrm{MeOH}, \mathrm{EtOH}, \mathrm{EA}$, and $\mathrm{AQ}$ ) of T. spruneriana was determined using HPLC-DAD and the obtained results are given in Table 2. The obtained results from the analysis of $T$. spruneriana extracts exposed the existence of 12 compounds, including caffeic acid, gallic acid, epicatechin, and quercetin.

Quercetin was the most abundant component in T. spruneriana extracts. The presence of quercetin has been demonstrated in many studies and has been used in traditional medicine for many diseases like cancer (Murakami, Ashida, \& Terao, 2008), chronic inflammation (García-Mediavilla et al., 2007), cardiovascular (Shankar, Singh, \& Srivastava, 2007), and obesity (Yang et al., 2008) due to its therapeutic features. Some authors have claimed that quercetin is an antioxidant (Karbarz \& Malyszko, 2008). On the contrary, some authors have reported that quercetin in plant plays a role in nutrient uptake, mycorrhizal network formation, and defense mechanism (Gholami, De Geyter, Pollier, Goormachtig, \& Goossens, 2014). After quercetin, the most abundant compounds in the plant were catechin, hydroxybenzoic acid, and cinnamic acid, respectively. Additionally, coumaric, cinnamic, and chlorogenic acid were observed in all tested extracts. Chlorogenic acid, a dietary polyphenol found in all extracts, has been shown to have a powerful role in the arrangement of the body's blood sugar homeostasis and dermal hyperpigmentation in previous studies (Fukushima et al., 2015).

In this study, chlorogenic acid, coumaric acid, gallic acid, caffeic acid, syringic acid, and t-ferulic acid were identified, and also $\mathrm{EtOH}$ extract can be interpreted as the richest extract in terms of bioactive compounds. But it was not so in terms of total phenolic and flavonoid content. Although many studies in the literature report that the high antioxidant activity of foods, beverages, or different plant extracts are directly related to their high phenolic content (Benabdallah, Rahmoune, Boumendjel, Aissi, \& Messaoud, 2016; Do et al., 2014), there are also reports stating that this is not always the case (Al-Musayeib, Perveen, Fatima, Nasir, \& Hussain, 2011; Aryal et al., 2019; Kähkönen et al., 1999). In the Folin-Ciocalteu assay, phenolic compounds are known to exhibit different antioxidant responses depending on their molecular structure. The hydrogen atoms of adjacent hydroxyl groups (o-diphenol) at different positions of the rings $(A, B$, and $C$ ) in the compound, the double bonds of the benzene ring and the double bond of the oxo functional group $(-\mathrm{C}=\mathrm{O})$ of some flavonoids ensure them with high antioxidant activity and this situation can be seen clearly in quercetin and catechin (Figure 2) (Minatel et al., 2017). Quercetin and catechin have similar hydroxyl groups at the same positions, but quercetin has a 2,3-double bond the $\mathrm{C}$ ring and the 4-oxo function, which allows quercetin to have higher antioxidant activity compared to the saturated heterocyclic ring of catechin (Rice-Evans, Miller, \& Paganga, 1996). Considering the results of HPLC in our study, catechin (6774.73 $\mu \mathrm{g} / \mathrm{g}$ extract), and quercetin $(3144.15 \mu \mathrm{g} / \mathrm{g}$ extract) were found in EtOH extract with the highest values. The EtOH extract had a lower TPC value compared to $\mathrm{MeOH}$ and EA extracts but showed higher antioxidant 


\begin{tabular}{|c|c|c|c|c|}
\hline \multirow[b]{2}{*}{ Phenolic components } & \multicolumn{4}{|l|}{ Extracts } \\
\hline & $\mathrm{MeOH}$ & EtOH & EA & $\mathrm{AQ}$ \\
\hline Gallic acid & 18.51 & 48.03 & nd & 34.59 \\
\hline Catechin & nd & 6774.73 & 4460.25 & 201.66 \\
\hline Chlorogenic Acid & 49.33 & 261.65 & 98.27 & 33.94 \\
\hline Caffeic acid & nd & nd & nd & 63.68 \\
\hline Hydroxybenzoic acid & nd & nd & nd & 1118.79 \\
\hline Epicatechin & nd & 73.99 & nd & nd \\
\hline Syringic acid & 53.18 & 36.49 & nd & nd \\
\hline Coumaric acid & 97.47 & 206.54 & 171.69 & 138.35 \\
\hline Ferulic acid & nd & 416.56 & 199.09 & nd \\
\hline Sinapic acid & 241.50 & nd & nd & nd \\
\hline Cinnamic acid & 192.93 & 283.09 & 156.43 & 84.65 \\
\hline Quercetin & 1489.86 & 3144.15 & 1800.01 & nd \\
\hline
\end{tabular}

TABLE 2 Polyphenolic compounds in different extracts of T. spruneriana ( $\mu \mathrm{g} / \mathrm{g}$ extract)

Abbreviation: nd, not detected.

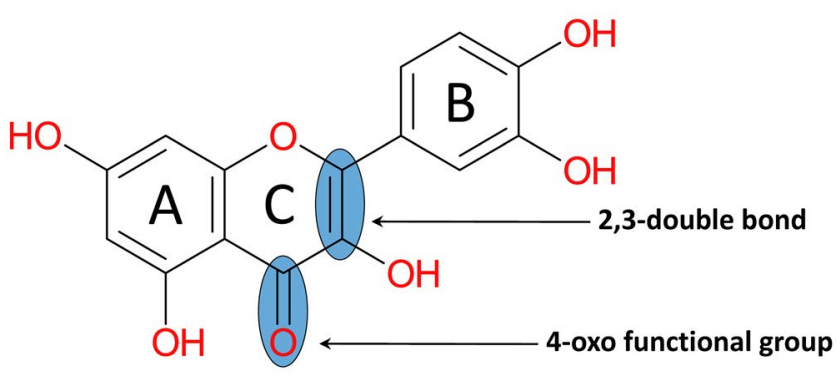

Quercetin<smiles>[CH2-][C@@H]1Oc2cc(O)cc(O)c2C[C@@H]1O</smiles>

(+)-Catechin

FIGURE 2 2,3-Double bond in the $\mathrm{C}$ ring and the 4-oxo function

TABLE 3 Enzyme inhibitory properties of the tested extracts

\begin{tabular}{|c|c|c|c|c|c|}
\hline \multirow[b]{2}{*}{ Extracts } & \multicolumn{2}{|c|}{ Cholinesterases inhibition } & \multicolumn{2}{|c|}{ Antidiabetic assay } & \multirow{2}{*}{$\begin{array}{l}\text { Hyperpigmentatio } \\
\text { Tyrosinase } \\
\text { inhibition } \\
\text { (mg KAE/g) }\end{array}$} \\
\hline & $\begin{array}{l}\text { AChE } \\
\text { Inhibition } \\
\text { (mg GALAE/g) }\end{array}$ & $\begin{array}{l}\text { BChE } \\
\text { Inhibition } \\
\text { (mg GALAE/g) }\end{array}$ & $\begin{array}{l}\alpha \text {-amylase } \\
\text { inhibition } \\
\text { (mmol ACAE/g) }\end{array}$ & $\begin{array}{l}\alpha \text {-glucosidase } \\
\text { inhibition } \\
\text { (mmol ACAE/g) }\end{array}$ & \\
\hline $\mathrm{MeOH}$ & $4.04 \pm 0.18$ & $5.67 \pm 0.70$ & $0.93 \pm 0.01$ & $1.81 \pm 0.04$ & $124.66 \pm 0.53$ \\
\hline $\mathrm{EtOH}$ & $5.22 \pm 0.01$ & $17.22 \pm 0.31$ & $0.98 \pm 0.04$ & $1.63 \pm 0.08$ & $122.72 \pm 1.81$ \\
\hline $\mathrm{AQ}$ & na & na & $0.20 \pm 0.01$ & $0.07 \pm 0.01$ & na \\
\hline
\end{tabular}

Note: Values expressed are means $\pm S D$ of three parallel measurements.

Abbreviations: ACAE, Acarbose equivalent; GALAE, Galantamine equivalent; KAE, Kojic acid equivalent; na, not active.

activity. This can be attributed to the variety and amount of phenolic compounds such as quercetin and catechin, which are found in $\mathrm{EtOH}$ extract and can show higher antioxidant activity.

In previous studies on Trigonella species, the presence of these compounds has been mentioned and this confirms our current study
(Hussain et al., 2016; Kenny et al., 2013). According to the results obtained in our study, different phenolic compounds were determined in variable amounts in $\mathrm{MeOH}, \mathrm{EtOH}, \mathrm{EA}$, and $\mathrm{AQ}$ extracts of T. spruneriana, and it was observed that the use of different extracts affected the quantity of phenolic compounds. 


\section{7 | In vitro enzyme inhibitory properties}

Inhibition of certain enzymes is considered as an important therapeutic tactic to struggle with many health problems and is important in controlling inappropriate body functions (Zengin et al., 2019). Cholinesterases are significant enzymes responsible for serious chronic diseases like Alzheimer's disease (AD). AChE inhibition play an important role for the control of $A D$ because AChE inhibitors, which can increase cholinergic transmission by precluding the degradation of acetylcholine, are used to mitigate symptoms of people with AD (Nisa et al., 2017). According to the results given in Table 3, all extracts except $A Q$ showed good inhibitory effect against both $\mathrm{AChE}$ and BChE. The EtOH extract exhibited maximum inhibition (17.22 $\pm 0.31 \mathrm{mg}$ GALAE/g) against BChE, followed by EA extract (12.30 $\pm 1.00 \mathrm{mg} \mathrm{GALAE} / \mathrm{g})$. Enzyme inhibition activities of these extracts may be based on their bioactive content as reported in previous studies (Kennedy \& Wightman, 2011; Mazlan et al., 2013). According to the data provided by Satheeshkumar, Mukherjee, Bhadra, and Saha (2010), Trigonella foenum graecum L. was able to inhibit AChE with an $\mathrm{IC}_{50}$ equal to $53.00 \pm 17.33 \mu \mathrm{g} / \mathrm{mL}$.

Controlling hyperglycemia aims to reduce the levels of blood glucose by inhibitory properties of the two main enzymes $\alpha$-amylase and $\alpha$-glucosidase in the carbohydrate metabolism (Kumar, Mehta, Satija, \& Garg, 2013). All Trigonella extracts exhibited the inhibitory properties for the enzymes of $\alpha$-amylase and $\alpha$-glucosidase. Although the plant extracts showed significant inhibition against $\alpha$-glucosidase $(1.94 \pm 0.01,1.81 \pm 0.04$, and $1.63 \pm 0.08 \mathrm{mmol}$ $\mathrm{ACAE} / \mathrm{g}$ for $\mathrm{EA}, \mathrm{MeOH}$, and $\mathrm{EtOH}$, respectively), a slight inhibition against $\alpha$-amylase $(0.96 \pm 0.02,0.93 \pm 0.01$, and $0.98 \pm 0.04 \mathrm{mmol}$ $\mathrm{ACAE} / \mathrm{g}$ for $\mathrm{EA}, \mathrm{MeOH}$, and $\mathrm{EtOH}$, respectively). In addition, the AQ extract showed poor inhibition for both enzymes. Studies on $T$. foenum graecum from the same genus with $T$. spruneriana have been reported to have low levels of the $\alpha$-amylase inhibitor (Kumar et al., 2013; Narkhede, 2012). The existence of phenolic compounds in $T$. spruneriana may be responsible for $\alpha$-amylase and $\alpha$-glucosidase enzyme inhibitory activity, and this situation has mentioned in the previous studies (Kennedy \& Wightman, 2011; Shang et al., 1998). At the same time, both $\alpha$-amylase and $\alpha$-glucosidase enzyme inhibitory activities were found to be statistically significant $(p<.05)$ with TPC and TFC.

Inhibition of tyrosinase, which is associated with skin hyperpigmentation disorders, has become a strategy to prevent excess production/accumulation of melanin in the skin. Due to the negative impacts of synthetic anti-tyrosinase agents, investigation of naturally derived tyrosinase inhibitors is required (Sarikurkcu, Zengin, et al., 2015). In this study, the inhibition of $T$. spruneriana extracts against tyrosinase enzyme was tested. Based on the results given in Table 3, maximum inhibition activity against tyrosinase enzyme was determined in $\mathrm{MeOH}$ extract (124.66 $\pm 0.53 \mathrm{mg} \mathrm{KAE} / \mathrm{g}$ ), followed by $\mathrm{EtOH}(122.72 \pm 1.81 \mathrm{mg} \mathrm{KAE} / \mathrm{g})$, and EA extract $(117.74 \pm 1.52 \mathrm{mg}$ $\mathrm{KAE} / \mathrm{g}$ ), respectively, yet, the $\mathrm{AQ}$ extract showed no inhibitory activity. On the contrary, Vaibhav and Lakshaman (2012) reported that leaves and seeds of $T$. foenum graceum $\mathrm{MeOH}$ and $\mathrm{AQ}$ extracts had anti-tyrosinase activity between $4.60 \%$ and $16.15 \%$.

\section{4 | CONCLUSION}

This study reports the phytochemical composition and antioxidant activities of the different extracts of the $T$. spruneriana plant. The study also is the first endeavor to investigate the enzyme inhibition activities that are closely related to common diseases such as $A D$, diabetes and hyperpigmentation. Based on our findings, the used different solvents like $\mathrm{MeOH}, \mathrm{EtOH}, \mathrm{EA}$, and $\mathrm{AQ}$ for extraction were found to have a significant effect on total phenolic and flavonoid contents. Also, the bioactive compounds present in $T$. spruneriana generally showed higher antioxidant activity in polar solvents like EtOH and $\mathrm{MeOH}$. It was highlighted that an extract with the highest total phenolic content does not always exhibit the highest biological activity, and this may be due to the variety of phenolic compounds and their quantities. Besides, T. spruneriana had a significant effect on all tested enzymes, and hence, can be seen as a potential source for future phyto-pharmaceuticals studies.

\section{ACKNOWLEDGMENTS}

We would like to thank botanist experts Dr. Mustafa Keskin for identifying the T. spruneriana plant.

\section{AUTHOR CONTRIBUTION}

Volkan Aylanc: Investigation; Methodology; Writing-original draft; Writing-review \& editing. Bulent Eskin: Formal analysis; Resources; Writing-original draft. Gokhan Zengin: Conceptualization; Formal analysis; Investigation; Methodology; Writing-original draft; Writingreview \& editing. Mehmet Dursun: Formal analysis; Methodology; Visualization; Writing-original draft. Yavuz Selim Cakmak: Formal analysis; Investigation; Methodology; Project administration; Resources; Supervision; Writing-original draft; Writing-review \& editing.

\section{ORCID}

Volkan Aylanc iD https://orcid.org/0000-0003-4060-766X

Gokhan Zengin (iD https://orcid.org/0000-0001-6548-7823

Yavuz Selim Cakmak iD https://orcid.org/0000-0001-8954-5485

\section{REFERENCES}

Abas, A. S. M., \& Naguib, D. M. (2019). Effect of germination on anticancer activity of Trigonella foenum seeds extract. Biocatalysis and Agricultural Biotechnology, 18, 101067. https://doi.org/10.1016/j. bcab.2019.101067

Aktumsek, A., Zengin, G., Guler, G. O., Cakmak, Y. S., \& Duran, A. (2013). Antioxidant potentials and anticholinesterase activities of methanolic and aqueous extracts of three endemic Centaurea L. species. Food and Chemical Toxicology, 55, 290-296. https://doi.org/10.1016/j. fct.2013.01.018 
Al-Musayeib, N., Perveen, S., Fatima, I., Nasir, M., \& Hussain, A. (2011). Antioxidant, anti-glycation and anti-inflammatory activities of phenolic constituents from cordia sinensis. Molecules, 16(12), 1021410226. https://doi.org/10.3390/molecules161210214

Alothman, M., Bhat, R., \& Karim, A. A. (2009). Antioxidant capacity and phenolic content of selected tropical fruits from Malaysia, extracted with different solvents. Food Chemistry, 115(3), 785-788. https://doi. org/10.1016/j.foodchem.2008.12.005

Altuntaş, E., Özgöz, E., \& Taşer, Ö. F. (2005). Some physical properties of fenugreek (Trigonella foenum-graceum L.) seeds. Journal of Food Engineering, 71(1), 37-43. https://doi.org/10.1016/j.jfood eng.2004.10.015

Aryal, S., Baniya, M. K., Danekhu, K., Kunwar, P., Gurung, R., \& Koirala, N. (2019). Total Phenolic content, Flavonoid content and antioxidant potential of wild vegetables from western Nepal. Plants, 8(4), 96. https://doi.org/10.3390/plants8040096

Avalos-Soriano, A., la Cruz-Cordero, D., Rosado, J., \& Garcia-Gasca, T. (2016). 4-Hydroxyisoleucine from fenugreek (Trigonella foenum-graecum): Effects on insulin resistance associated with obesity. Molecules, 21(11), 1596. https://doi.org/10.3390/molecules2 1111596

Benabdallah, A., Rahmoune, C., Boumendjel, M., Aissi, O., \& Messaoud, C. (2016). Total phenolic content and antioxidant activity of six wild Mentha species (Lamiaceae) from northeast of Algeria. Asian Pacific Journal of Tropical Biomedicine, 6(9), 760-766. https://doi. org/10.1016/j.apjtb.2016.06.016

Benziane, M. N. A., Acem, K., Aggad, H., \& Abdali, M. (2019). Phytochemistry, HPLC profile and antioxidant activity of aqueous extracts of fenugreek (Trigonella foenum graecum L.) seeds grown in arid zones of Algeria. Acta Scientifica Naturalis, 6(2), 71-87. https:// doi.org/10.2478/asn-2019-0020

Bhanger, M. I., Bukhari, S. B., \& Memon, S. (2008). Antioxidative activity of extracts from a Fenugreek seeds (Trigonella foenum-graecum). Pakistan Journal of Analytical \& Environmental Chemistry, 9(2), 6.

Burton-Freeman, B. (2000). Dietary fiber and energy regulation. The Journal of Nutrition, 130(2), 272-275. https://doi.org/10.1093/ jn/130.2.272S

Caponio, F., Alloggio, V., \& Gomes, T. (1999). Phenolic compounds of virgin olive oil: Influence of paste preparation techniques. Food Chemistry, 64(2), 203-209. https://doi.org/10.1016/S0308-8146(98)00146-0

Carocho, M., Barreiro, M. F., Morales, P., \& Ferreira, I. C. F. R. (2014). Adding molecules to food, pros and cons: A review on synthetic and natural food additives. Comprehensive Reviews in Food Science and Food Safety, 13(4), 377-399. https://doi.org/10.1111/1541-4337.12065

CF Bodewes, T., Luttikhold, J., FM van Stijn, M., Visser, M., van Norren, K., AR Vermeulen, M., \& AM van Leeuwen, P. (2011). Antioxidative properties of flavonoids. Current Organic Chemistry, 15(15), 26162626. https://doi.org/10.2174/138527211796367282

Chandra, K., Salman, A. S., Mohd, A., Sweety, R., \& Ali, K. N. (2015). Protection against FCA induced oxidative stress induced DNA damage as a model of arthritis and in vitro anti-arthritic potential of costus speciosus rhizome extract. International Journal of Pharmacognosy and Phytochemical Research, 7(2), 383-389.

Chatterjee, S., Variyar, P. S., \& Sharma, A. (2009). Stability of lipid constituents in radiation processed fenugreek seeds and turmeric: Role of phenolic antioxidants. Journal of Agricultural and Food Chemistry, 57(19), 9226-9233. https://doi.org/10.1021/jf901642e

da Silva, B. V., Barreira, J. C. M., \& Oliveira, M. B. P. P. (2016). Natural phytochemicals and probiotics as bioactive ingredients for functional foods: Extraction, biochemistry and protected-delivery technologies. Trends in Food Science \& Technology, 50, 144-158. https:// doi.org/10.1016/j.tifs.2015.12.007

Do, Q. D., Angkawijaya, A. E., Tran-Nguyen, P. L., Huynh, L. H., Soetaredjo, F. E., Ismadji, S., \& Ju, Y. H. (2014). Effect of extraction solvent on total phenol content, total flavonoid content, and antioxidant activity of Limnophila aromatica. Journal of Food and Drug Analysis, 22(3), 296-302. https://doi.org/10.1016/j.jfda.2013.11.001

Esmaeili, A., Rashidi, B., \& Rezazadeh, S. (2012). Biological activities of various extracts and chemical composition of Trigonella monantha CA Mey. subsp. monantha grown in Iran. Iranian Journal of Pharmaceutical Research: IJPR, 11(4), 1127.

Fratianni, F., Tucci, M., De Palma, M., Pepe, R., \& Nazzaro, F. (2007). Polyphenolic composition in different parts of some cultivars of globe artichoke (Cynara cardunculus L. var. scolymus (L.) Fiori). Food Chemistry, 104(3), 1282-1286. https://doi.org/10.1016/j.foodc hem.2007.01.044

Fukushima, Y., Takahashi, Y., Hori, Y., Kishimoto, Y., Shiga, K., Tanaka, Y., ... Kondo, K. (2015). Skin photoprotection and consumption of coffee and polyphenols in healthy middle-aged $\mathrm{J}$ apanese females. International Journal of Dermatology, 54(4), 410-418. https://doi. org/10.1111/ijd.12399

Gandhi, S., \& Abramov, A. Y. (2012). Mechanism of oxidative stress in neurodegeneration. Oxidative Medicine and Cellular Longevity, 2012, 1-11. https://doi.org/10.1155/2012/428010

García-Mediavilla, V., Crespo, I., Collado, P. S., Esteller, A., SánchezCampos, S., Tuñón, M. J., \& González-Gallego, J. (2007). The anti-inflammatory flavones quercetin and kaempferol cause inhibition of inducible nitric oxide synthase, cyclooxygenase- 2 and reactive C-protein, and down-regulation of the nuclear factor kappaB pathway in Chang Liver cells. European Journal of Pharmacology, 557(2-3), 221-229. https://doi.org/10.1016/j.ejphar.2006.11.014

Genkinger, J. M., Platz, E. A., Hoffman, S. C., Comstock, G. W., \& Helzlsouer, K. J. (2004). Fruit, vegetable, and antioxidant intake and all-cause, cancer, and cardiovascular disease mortality in a community-dwelling population in Washington County. Maryland. American Journal of Epidemiology, 160(12), 1223-1233. https://doi. org/10.1093/aje/kwh339

Gholami, A., De Geyter, N., Pollier, J., Goormachtig, S., \& Goossens, A. (2014). Natural product biosynthesis in Medicago species. Natural Product Reports, 31(3), 356-380. https://doi.org/10.1039/c3np7 0104b

Gong, Y., Liu, X., He, W. H., Xu, H. G., Yuan, F., \& Gao, Y. X. (2012). Investigation into the antioxidant activity and chemical composition of alcoholic extracts from defatted marigold (Tagetes erecta L.) residue. Fitoterapia, 83(3), 481-489. https://doi.org/10.1016/j. fitote.2011.12.013

Güngör, Ş. S. U., Güzel, S., İlçim, A., \& Kökdil, G. (2014). Total phenolic and flavonoid content, mineral composition and antioxidant potential of Trigonella monspeliaca. Turkish Journal of Pharmaceutical Sciences, 11(3), 255-262.

Gupta, S., \& Prakash, J. (2009). Studies on Indian green leafy vegetables for their antioxidant activity. Plant Foods for Human Nutrition, 64(1), 39-45. https://doi.org/10.1007/s11130-008-0096-6

Huang, D., Ou, B., \& Prior, R. L. (2005). The chemistry behind antioxidant capacity assays. Journal of Agricultural and Food Chemistry, 53(6), 1841-1856. https://doi.org/10.1021/jf030723c

Hussain, P. R., Suradkar, P., Javaid, S., Akram, H., \& Parvez, S. (2016). Influence of postharvest gamma irradiation treatment on the content of bioactive compounds and antioxidant activity of fenugreek (Trigonella foenum-graceum L.) and spinach (Spinacia oleracea L.) leaves. Innovative Food Science \& Emerging Technologies, 33, 268-281. https://doi.org/10.1016/j.ifset.2015.11.017

Jaradat, N. A., Shawahna, R., Hussein, F., \& Al-Lahham, S. (2016). Analysis of the antioxidant potential in aerial parts of Trigonella arabica and Trigonella berythea grown widely in Palestine: A comparative study. European Journal of Integrative Medicine, 8(5), 623-630. https://doi. org/10.1016/j.eujim.2016.04.004

Joana Gil-Chávez, G., Villa, J. A., Fernando Ayala-Zavala, J., Basilio Heredia, J., Sepulveda, D., Yahia, E. M., \& González-Aguilar, G. A. (2013). Technologies for extraction and production of bioactive 
compounds to be used as nutraceuticals and food ingredients: An overview. Comprehensive Reviews in Food Science and Food Safety, 12(1), 5-23. https://doi.org/10.1111/1541-4337.12005

Kähkönen, M. P., Hopia, A. I., Vuorela, H. J., Rauha, J. P., Pihlaja, K., Kujala, T. S., \& Heinonen, M. (1999). Antioxidant activity of plant extracts containing phenolic compounds. Journal of Agricultural and Food Chemistry, 47(10), 3954-3962. https://doi.org/10.1021/ jf990146I

Karbarz, M., \& Malyszko, J. (2008). Voltammetric behavior of trolox in methanol and ethanol solutions. Electroanalysis: an International Journal Devoted to Fundamental and Practical Aspects of Electroanalysis, 20(17), 1884-1890. https://doi.org/10.1002/elan.200804263

Kennedy, D. O., \& Wightman, E. L. (2011). Herbal extracts and phytochemicals: Plant secondary metabolites and the enhancement of human brain function. Advances in Nutrition, 2(1), 32-50. https://doi. org/10.3945/an.110.000117

Kenny, O., Smyth, T. J., Hewage, C. M., \& Brunton, N. P. (2013). Antioxidant properties and quantitative UPLC-MS analysis of phenolic compounds from extracts of fenugreek (Trigonella foenum-graecum) seeds and bitter melon (Momordica charantia) fruit. Food Chemistry, 141(4), 4295-4302. https://doi.org/10.1016/j.foodc hem.2013.07.016

Khandani, S., Assadi, M., Nejadsatari, T., \& Mehregan, I. (2016). Phenetic analysis of the genera medicagoid Trigonella, Medicago and Melilotus (Fabaceae) on seed coat in Iran. Biodiversitas Journal of Biological Diversity, 17(1), 162-171. https://doi.org/10.13057/biodiv/d170124

Kumar, P., Mehta, M., Satija, S., \& Garg, M. (2013). Enzymatic in vitro anti-diabetic activity of few traditional Indian medicinal plants. Journal of Biological Sciences, 13(6), 540-544. https://doi.org/10.3923/ jbs.2013.540.544

Mabberley, D. J. (1997). The plant-book: A portable dictionary of the vascular plants. Cambridge, UK: Cambridge University Press.

Martin, E., Akan, H., Ekici, M., \& Aytac, Z. (2011). New chromosome numbers in the genus Trigonella L. (Fabaceae) from Turkey. African Journal of Biotechnology, 10(2), 116-125. https://doi.org/10.5897/AJB10.972

Mazlan, N. A., Mediani, A., Abas, F., Ahmad, S., Shaari, K., Khamis, S., \& Lajis, N. H. (2013). Antioxidant, antityrosinase, anticholinesterase, and nitric oxide inhibition activities of three Malaysian Macaranga species. The Scientific World Journal, 2013. https://doi. org/10.1155/2013/312741

Minatel, I. O., Borges, C. V., Ferreira, M. I., Gomez, H. A. G., Chen, C.-Y.-O., \& Lima, G. P. P. (2017). Phenolic compounds: Functional properties, impact of processing and bioavailability. In M. Soto-Hernandez, M. Palma-Tenango, \& M. d. R. Garcia-Mateos (Eds.), Phenolic compounds - Biological activity (pp. 1-24). Janeza, Rijeka, Crotia: InTech. https:// doi.org/10.5772/66368

Murakami, A., Ashida, H., \& Terao, J. (2008). Multitargeted cancer prevention by quercetin. Cancer Letters, 269(2), 315-325. https://doi. org/10.1016/j.canlet.2008.03.046

Narkhede, M. B. (2012). Evaluation of alpha amylase inhibitory potential of four traditional culinary leaves. Asian Journal of Pharmaceutical and Clinical Research, 5(Suppl 2), 75-76.

Nićiforović, N., Mihailović, V., Mašković, P., Solujić, S., Stojković, A., \& Muratspahić, D. P. (2010). Antioxidant activity of selected plant species; potential new sources of natural antioxidants. Food and Chemical Toxicology, 48(11), 3125-3130. https://doi.org/10.1016/j. fct.2010.08.007

Nisa, M., Munawar, M. A., Iqbal, A., Ahmed, A., Ashraf, M., Qurra-tul-Ann, A. G., \& Khan, M. A. (2017). Synthesis of novel 5-(aroylhydrazinocarbonyl) escitalopram as cholinesterase inhibitors. European Journal of Medicinal Chemistry, 138, 396-406. https://doi.org/10.1016/j. ejmech.2017.06.036

Premanath, R., Sudisha, J., Lakshmi Devi, N., \& Aradhya, S. M. (2011). Antibacterial and anti-oxidant activities of fenugreek (Trigonella foenum graecum L.) leaves. Journal Medicinal Plants Resereach, 5(6), 695-705. https://doi.org/10.3923/rjmp.2011.695.705

Rajagopalan, M. S. (1998). Fenugreek, what this herb can offer. Naturally, 1, 1-4.

Ranjbar, M., \& Zahra, H. (2016). Chromosome numbers and biogeography of the genus Trigonella (Fabaceae). Caryologia, 69(3), 223-234. https://doi.org/10.1080/00087114.2016.1169090

Rice-Evans, C. A., Miller, N. J., \& Paganga, G. (1996). Structure-antioxidant activity relationships of flavonoids and phenolic acids. Free Radical Biology and Medicine, 20(7), 933-956. https://doi.org/10.1016/08915849(95)02227-9

Rochette, L., Lorin, J., Zeller, M., Guilland, J.-C., Lorgis, L., Cottin, Y., \& Vergely, C. (2013). Nitric oxide synthase inhibition and oxidative stress in cardiovascular diseases: Possible therapeutic targets? Pharmacology \& Therapeutics, 140(3), 239-257. https://doi. org/10.1016/j.pharmthera.2013.07.004

Rusak, G., Komes, D., Likić, S., Horžić, D., \& Kovač, M. (2008). Phenolic content and antioxidative capacity of green and white tea extracts depending on extraction conditions and the solvent used. Food Chemistry, 110(4), 852-858. https://doi.org/10.1016/j.foodc hem.2008.02.072

Sarikurkcu, C., Uren, M. C., Tepe, B., Cengiz, M., \& Kocak, M. S. (2015). Phlomis armeniaca: Phenolic compounds, enzyme inhibitory and antioxidant activities. Industrial Crops and Products, 78, 95-101. https:// doi.org/10.1016/j.indcrop.2015.10.016

Sarikurkcu, C., Zengin, G., Oskay, M., Uysal, S., Ceylan, R., \& Aktumsek, A. (2015). Composition, antioxidant, antimicrobial and enzyme inhibition activities of two Origanum vulgare subspecies (subsp. vulgare and subsp. hirtum) essential oils. Industrial Crops and Products, 70, 178-184. https://doi.org/10.1016/j.indcrop.2015.03.030

Satheeshkumar, N., Mukherjee, P. K., Bhadra, S., \& Saha, B. P. (2010). Acetylcholinesterase enzyme inhibitory potential of standardized extract of Trigonella foenum graecum $\mathrm{L}$ and its constituents. Phytomedicine, 17(3-4), 292-295. https://doi.org/10.1016/j. phymed.2009.06.006

Sathisha, A. D., Lingaraju, H. B., \& Prasad, K. S. (2011). Evaluation of antioxidant activity of medicinal plant extracts produced for commercial purpose. Journal of Chemistry, 8(2), 882-886. https://doi. $\operatorname{org} / 10.1155 / 2011 / 693417$

Shahat, A. A., Ibrahim, A. Y., \& Alsaid, M. S. (2015). Antioxidant capacity and polyphenolic content of seven Saudi Arabian medicinal herbs traditionally used in Saudi Arabia. Indian Journal of Traditional Knowledge, 1(1), 28-35.

Shang, M., Cai, S., Han, J., Li, J., Zhao, Y., Zheng, J., ... Fan, W. (1998). Studies on flavonoids from Fenugreek (Trigonella foenumgraecum L.). Zhongguo Zhong Yao Za Zhi= Zhongguo Zhongyao Zazhi= China Journal of Chinese Materia Medica, 23(10), 614-616, 639.

Shankar, S., Singh, G., \& Srivastava, R. K. (2007). Chemoprevention by resveratrol: Molecular mechanisms and therapeutic potential. Frontiers in Bioscience, 12(12), 4839-4854. https://doi.org/10.2741/2432

Shankaracharya, N. B., Anandaraman, S., \& Natarajan, C. P. (1973). Chemical composition of raw and roasted fenugreek seeds. Journal of Food Science and Technology, 10(4), 179-181.

Singh, P., Singh, U., Shukla, M., \& Singh, R. L. (2010). Variation of some phytochemicals in methi and saunf plants at different stages of development. Journal of Herbal Medicine and Toxicology, 4(2), 93-99.

Smeriglio, A., Mandalari, G., Bisignano, C., Filocamo, A., Barreca, D., Bellocco, E., \& Trombetta, D. (2016). Polyphenolic content and biological properties of Avola almond (Prunus dulcis Mill. DA Webb) skin and its industrial byproducts. Industrial Crops and Products, 83, 283-293. https://doi.org/10.1016/j.indcrop.2015.11.089

Srinivasan, K. (2006). Fenugreek (Trigonella foenum-graecum): A review of health beneficial physiological effects. Food Reviews International, 22(2), 203-224. https://doi.org/10.1080/87559120600586315 
Sultana, B., Anwar, F., \&Ashraf, M. (2009). Effect of extraction solvent/technique on the antioxidant activity of selected medicinal plant extracts. Molecules, 14(6), 2167-2180. https://doi.org/10.3390/molecules14062167

Uras Güngör, S. Ş., İlçim, A., \& Kökdil, G. (2017). A comparison of diosgenin, phenolics, fatty acid profiles and mineral contents with free radical scavenging activity of Trigonella L. species from section cylindricae. Records of Natural Products, 11(1), 17-30.

Uysal, S., Zengin, G., Locatelli, M., Bahadori, M. B., Mocan, A., Bellagamba, G., ... Aktumsek, A. (2017). Cytotoxic and enzyme inhibitory potential of two potentilla species (P. speciosa L. and P. reptans Willd.) and their chemical composition. Frontiers in Pharmacology, 8, 290. https:// doi.org/10.3389/fphar.2017.00290

Vaibhav, S., \& Lakshaman, K. (2012). Tyrosinase enzyme inhibitory activity of selected Indian herbs. International Journal of Research in Pharmaceutical and Biomedical Sciences, 3, 977-982.

Willett, W. C. (2002). Balancing life-style and genomics research for disease prevention. Science, 296(5568), 695-698. https://doi. org/10.1126/science.1071055

Yang, J.-Y., Della-Fera, M. A., Rayalam, S., Ambati, S., Hartzell, D. L., Park, H. J., \& Baile, C. A. (2008). Enhanced inhibition of adipogenesis and induction of apoptosis in 3T3-L1 adipocytes with combinations of resveratrol and quercetin. Life Sciences, 82(19-20), 1032-1039. https://doi.org/10.1016/j.Ifs.2008.03.003
Zengin, G., Sieniawska, E., Senkardes, I., Picot-Allain, M. C. N., Sinan, K. I., \& Mahomoodally, M. F. (2019). Antioxidant abilities, key enzyme inhibitory potential and phytochemical profile of Tanacetum poteriifolium Grierson. Industrial Crops and Products, 140, 111629. https:// doi.org/10.1016/j.indcrop.2019.111629

\section{SUPPORTING INFORMATION}

Additional supporting information may be found online in the Supporting Information section.

How to cite this article: Aylanc V, Eskin B, Zengin G, Dursun

$M$, Cakmak YS. In vitro studies on different extracts of fenugreek (Trigonella spruneriana BOISS.): Phytochemical profile, antioxidant activity, and enzyme inhibition potential. J Food Biochem. 2020;00:e13463. https://doi.org/10.1111/jfbc.13463 